\title{
Non-drug treatments and rehabilitation of patients with bronchial asthma
}

\author{
Mytskan B.M., Ostapiak Z.M., Mytskan T.S. \\ Vasyl Stefanyk Precarpathian National University
}

\section{DOI: https://doi.org/10.34142/HSR.2020.06.02.02}

\section{Abstract}

The aim is to analyze the effectiveness of non-drug methods of treatment and rehabilitation of children and adults with bronchial asthma.

Methods. To realize the purpose of the study, a system-functional analysis of special literature and materials of the Internet was used. Results. The standard approach to antiasthmatic therapy does not always lead to a controlled course. Reducing the impact of allergens both in the home and in the workplace is an effective measure to control the disease. Phytotherapy and reflexology are widely and effectively used. Diet therapy is ineffective, the use of vitamin D in the treatment and rehabilitation of patients with bronchial asthma is encouraging. The vaccine does not increase the risk of the disease, but it is not effective for prevention. Increasing physical activity is the most effective method of rehabilitating patients. Evidence from recent studies suggests that interventions aimed at eliminating a single allergen may be effective in reducing allergen levels and asthma incidence, and this approach deserves further study. Currently, a comprehensive multifaceted study of acupuncture, which will be able to provide reliable clinical evidence of the effectiveness of acupuncture for the treatment and prevention of asthma. At the same time, there is a need for comprehensive research in the field of phytotherapy and training of respiratory muscles.

Conclusion. Non-drug methods of prevention and rehabilitation are widely used (as additional) in bronchial asthma. Despite many years of use of phytotherapy, acupuncture, breathing exercises in the treatment and rehabilitation of asthma, so far there are no clear recommendations for their use: indications, dosage, duration, frequency and the lack of standardization makes it difficult to use them. Key words: bronchial asthma, non-drug rehabilitation, physical exercises.

\section{Анотація}

Мицкан Б.М., Остап'як 3.М., Мицкан Т.С. Немедикаментозні методи лікування і реабілітація хворих на бронхіальну астму Мета - проаналізувати ефективність немедикаментозних методів лікуваня та реабілітації дітей і дорослих з бронхіальною астмою.

Методи. Для реалізації мети дослідження був використаний системно-функціональний аналіз спеціальної літератури та матеріалів мережі інтернет.

Результати. Стандартний підхід до протиастматичної терапії не завжди призводить до досягнення контрольованого перебігу. Зменшення впливу алергенів як в житлових приміщеннях, так і на робочому місці, $\epsilon$ дієвим заходом для контролю захворювання. Широко і ефективно використовуються фітотерапія і рефлексотерапія. Дієтотерапія малоефективна, обнайділиво використання вітаміну Д в лікуванні і реабілітації хворих бронхіальною астмою. Вакцинція не збільшує ризик захворювання, але і не ефективна для профілактики. Підвищення фізичної активності найбільш дієвий метод реабілітації пацієнтів. Докази останніх досліджень показують, що втручання, спрямовані на елімінацію одного алергену, можуть бути ефективними для зниження рівня алергену і захворюваності на астму, і цей підхід заслуговує на подальше вивчення. На теперішній час проводяться багатогранне комплексне дослідження іглорефлексотерапії, яке буде в змозі надати надійні клінічні докази ефективності голкотерапії для лікування і профілактики бронхіальної астми. Водночас $€$ потреба в багатокомплексних дослідженнях в області фітотерапії та тренування дихальних м'язів.

Висновок. Немедикаментозні методи профілактики і реабілітації широко використуються (як додаткові) при бронхіальній астмі. Незважаючи на багаторічні застосування фітотерапії, голкорефлексотерапії, дихальних вправ в лікуванні та реабілітації бронхіальної астми, до теперішнього часу не має чітких рекомендацій для їх застосування: показання, дозування, тривалість, періодичність.. Ефективними виявилися навчально-освітні програми самоконтролю захворювання, але велика кількість їх відсутність стандартизації викликає труднощі для їх використання.

Ключові слова: бронхіальна астма, немедикаментозна реабілітація, фізичні вправи.

\section{Аннотация}

Мыцкан Б.М., Остапяк 3.М., Мыцкан Т.С. Немедикаментозные методы лечения и реабилитация больных бронхиальной астмой Цель - проанализировать эффективность немедикаментозных методов лечения и реабилитации детей и взрослых с бронхиальной астмой.

Методы. Для реализации цели исследования был использован системно-функциональный анализ специальной литературы и материалов сети интернет.

Результаты. Стандартный подход к противоастматической терапии не всегда приводит к достижению контролируемого течения. Уменьшение влияния аллергенов как в жилых помещениях, так и на рабочем месте является действенной мерой для контроля заболевания. Широко и эффективно используются фитотерапия и рефлексотерапия. Диетотерапия малоэффективна, обнадеживает использования витамина Д в лечении и реабилитации больных с бронхиальной астмой. Вакцинция не увеличивает риск заболевания, но и не эффективна для профилактики. Повышение физической активности наиболее действенный метод реабилитации пациентов.

Доказательства последних исследований показывают, что вмешательства, направленные на элиминацию одного аллергена, могут быть эффективными для снижения уровня аллергена и заболеваемости астмой, и этот подход заслуживает дальнейшего изучения. В настоящее время проводятся многогранное комплексное исследование иглорефлексотерапии, которая будет в состоянии предоставить надежные клинические доказательства эффективности иглотерапии для лечения и профилактики бронгхиальной астмы. Есть потребность в багатокомплексних исследованиях в области фитотерапии, тренировки дыхательны мышц.

Вывод. Немедикаментозные методы профилактики и реабилитации широко используются (как дополнительные) при бронхиальной астме. Несмотря на многолетние применения фитотерапии, иглорефлексотерапии, дыхательных упражнений в лечении и реабилитации бронхиальной астмы, до настоящего времени нет четких рекомендаций для их применения: показания, дозировка, продолжительность, периодичность. Эффективными оказались учебно-образовательные программы самоконтроля заболевания, но большое количество их и отсутствие стандартизации вызывает трудности для их использования. Ключевые слова: бронхиальная астма, немедикаментозная реабилитация, физические упражнения. 


\section{Introduction}

Bronchial asthma continues to be a major public health problem in the world. According to official statistics, the prevalence of asthma in the world ranges from 1 to $16 \%$. About 300 million people suffer from asthma worldwide $[1,2]$. The recommendations of the Global Asthma Initiative (GINA) in 2004 marked the transition from the concept of severity to the concept of asthma control, which is assessed on the basis of disease activity over the past four weeks, the frequency of respiratory symptoms and their impact on daily life. The effectiveness of medical treatment of asthma is well recognized [3]. Asthma mortality has decreased in recent years, most likely due to new treatments and clinical guidelines, but many other factors are also associated with asthma control, including allergens, air pollutants, viral infections, food, medications, obesity, psychoemotional stress. Patients with asthma often suffer from comorbidities, and these comorbid conditions can interfere with asthma control. Given the high prevalence of this disease and the associated costs, it is not surprising that the search for new effective treatments for the prevention and rehabilitation of bronchial asthma is given considerable effort and money [4, 5]. The standard approach to antiasthmatic therapy does not always lead to a controlled course, and therefore many scientific studies offer complementary (additional, non-drug) methods of prevention, treatment and rehabilitation of asthma in both children and adults $[6,7,8,9,10]$.

The aim: to evaluate the effectiveness of nondrug methods of prevention and rehabilitation of bronchial asthma in children and adults.

\section{Material and methods}

To realize the purpose of the study, a systemfunctional analysis of special literature and materials of the Internet was used. and rehabilitation of bronchial asthma in children and adults.

\section{Results}

Elimination of allergens. In recent decades, significant progress has been made in understanding the role of allergens in the room for bronchial asthma. Epidemiological studies have confirmed that people with asthma who are sensitized to household allergens have a more severe asthma phenotype, and that sensitization and exposure to allergens may be an important factor in asthma incidence $[11,12]$. In relation to bronchial asthma elimination is the elimination from the patient's environment of various factors, primarily causative allergens (fungal spores, mites, cockroaches, house dust and epithelial materials), which can exacerbate the disease and increase the risk of worsening its clinical manifestations. Therefore, elimination is one of the most important pathogenetic methods of treatment and prevention of bronchial asthma [13, 14]. A number of studies have shown that non-compliance with the elimination regime, even against the background of adequate basic therapy, leads to increased symptoms of bronchial asthma and does not achieve complete control over the disease [15]. In pregnant women, the level of IgE in the umbilical cord blood increases and, accordingly, the risk of developing bronchial asthma in the baby increases when the mother is sensitized to a household allergen [16]. Comprehensive avoidance of contact with allergens in the first year of life is effective in preventing the disease in adulthood [17].

Renovation of homes, partially or completely, as well as school premises, to reduce exposure to allergens and pollution, as well as cleaning and heating the air with a filter system has little effect on controlling asthma in adults and reducing the frequency of emergency care for children $[18,19,20]$. Systems that use ionizers or dehumidifiers in children's rooms are not effective [21, 22 ], in addition, these devices emit nitric oxide, which is a trigger for asthma [23]. Reducing the time of contact with allergens at work has no effect, but changing the place of work, in some cases, is appropriate [24, 25].

Many studies have shown a direct link between a significant reduction in allergens of cockroaches, mites [26, 27], mice [28, 29], fungi [30] and the clinical picture of the disease and control of bronchial asthma, but the type of allergen is important, exposure, seasonality, which must be taken into account when carrying out elimination measures [27, 31, 32].

The results of randomized clinical trials on the effectiveness of acaricides to reduce the level of house dust mites have shown mixed results. Some acaricides were not effective enough, others showed their effectiveness only in a set of elimination measures [33].

A number of studies and scientific reviews have reported a reduction in allergic sensitization in individuals who had contact with pets in childhood, but the clinical significance of this has not been recognized [34]. Another aspect of bronchial asthma prevention is the avoidance of inhalation of tobacco smoke, especially among patients with chronic respiratory diseases, as well as maternal smoking during pregnancy, which adversely affects the lung function of the child [35].

Analyzing the work on the elimination of various allergens (acaricides, air purification, removal of carpets, mold, mattresses, removal of pets, pest control, the use of devices for filtering solid particles) Leas BF et al. [36] concluded that isolated measures to control allergens were inconclusive or ineffective, while multicomponent measures improved asthma control and reduced the number of emergency calls. What combinations of methods for allergen removal are the most effective at present could not be determined due to the small number of studies in this direction [36, 37].

According to GINA, there is a heterogeneous level of evidence for some measures to reduce allergens in the open air or indoor air pollution, but in such conditions it is advisable to avoid physical activity accompanied by forced breathing [3].

Vaccination. All childhood immunizations should be performed according to the calendar, as there is no evidence of an increased risk of asthma [38]. The Cochrane Review did not show a positive effect of 
vaccination (influenza, pneumococcal) on patients with asthma [39].

Diet therapy. According to a meta-analysis of special literature, diets for bronchial asthma are enriched with vitamin $\mathrm{C}$, unsaturated fatty acids or selenium, reducing sodium chloride, monosodium glutamate do not reduce the incidence and do not affect the course of bronchial asthma [40, 41, 42]. However, as shown by studies Tarazona-Meza CE, Hanson C, Pollard SL, Romero Rivero KM, Galvez Davila RM, Talegawkar S.et.al. [43], diet modification can potentially affect the prevalence of the disease. Oral magnesium supplements lead to an improvement in external respiration (FEV1), which was demonstrated only after eight weeks, but no effect on any other indicators was detected and therefore further research is needed [44]. A Cochrane study of a diet for weight loss in patients with bronchial asthma showed that this could lead to a short-term reduction in the dose of drugs and with a statistically significant improvement in FEV1 and FVC [45]. However, there is strong evidence that being overweight or obese increases the risk of developing asthma in children and adults of both sexes [46, 47, 48]. Vitamin C supplementation may be an inexpensive and simple approach to reducing the effects of smoking during pregnancy on neonatal lung function and respiratory disease [49].

With mild to moderate asthma, vitamin D treatment reduces the risk of asthma exacerbations in both children and adults [50], and high vitamin D levels in newborns may reduce the risk of developing bronchial asthma at 3-9 years of age and indicate that vitamin D is important. for normal immunogenic status and lung development, but there are currently no clear clinical guidelines [51, 52].

It is known that the imbalance in the intestinal microflora is associated with a higher risk of allergies. The ability of probiotics to restore intestinal microbiota may be effective in the prevention and treatment of bronchial asthma. In clinical practice, lactobacilli modulate serum cytokines in patients with bronchial asthma and reduce eosinophilia, but do not eliminate clinical symptoms [53]. In the experiment, bifidobacteria stimulated Th1 and inhibited immune responses to Th2 in allergies [54]. In infants at high risk of developing allergic diseases, taking probiotics did not reduce the risk of disease in the first two years of life [55].

Phytotherapy. Scientific phytotherapeutic studies at the level of molecular and cellular mechanisms of asthma have shown that many plants have metabolites that can be effectively used in the treatment and rehabilitation of bronchial asthma with fewer side effects [56], in particular by reducing the synthesis of proinflammatory mediator that stimulates eosinophils, basophils and labrocytes prior to cytokine release for $\mathrm{T}$-helper cell differentiation [57]. The first clinical trials of curcumin in bronchial asthma, which has anti-inflammatory effects but no significant clinical effect, require additional clinical evaluation with more patients, a higher tolerance dose and longer use [58].
The positive effect of bronchial asthma treatment with herbal preparations has been shown in the works of many scientists $[59,60,61]$

Speleotherapy. This method is practically unknown in Great Britain and the United States, but is widespread in some countries of Central and Eastern Europe $[62,63]$. The results of the study in the experiment indicate that speleotherapy induces changes in the morphology and protein expression of lung cells and skin fibroblasts in vitro, and these changes may determine the therapeutic effect of speleotherapy [64]. After the rehabilitation process of patients with bronchial asthma, including speleotherapy, there was an improvement in clinical manifestations and immune parameters in overweight patients [63]. The combined use of rehabilitation technologies for patients with partially controlled asthma, which included cryomassage and speleotherapy also gives a pronounced anti-inflammatory and immunocorrective effect and improved external respiration [65], and re-treatment in salt mines increases the effectiveness of the effect by normalizing the indicators of nonspecific reducing the intensity of the inflammatory process, mainly allergic in nature of the bronchial mucosa [66].

Acupuncture. One of the most important complementary and alternative methods of therapy and rehabilitation is acupuncture, which has been used to treat various diseases for over 2,000 years. In 1979, the WHO officially recommended acupuncture as a means of rehabilitation for patients with bronchial asthma.

The British Thoracic Society recommends that health professionals be aware of the common use of complementary and alternative medicine in the treatment of asthma, including acupuncture [67]. Yang Y.'s study of singing. [68] show that acupuncture is effective in relieving asthma symptoms and has a regulatory effect on local and cellular immunity in patients with bronchial asthma and can be used as an adjunct to conventional drug treatment and rehabilitation of patients with this pathology. Despite many published randomized clinical trials evaluating acupuncture in the treatment of asthma, clear and convincing evidence of its effectiveness has not been established [69].

Physical activity. The main function of physical activity is mobility and the ability to adapt to the performance, if necessary, of stressful physical exertion in patients with bronchial asthma. The level of physical maladaptation - one of the main psycho-emotional stress causes that interfere with the patient's normal lifestyle remains quite high $[67,70]$. For patients with bronchial asthma, exercise is a common adjunct to medical treatment [71], even in harsh climates (northern Finland) [72]. Deficiency of physical activity in early school age is not the cause of asthma in later life, but is associated with a decrease in FEV1 / FVC in older age [73]. Properly dosed exercise does not cause any side effects and does not aggravate the symptoms of the disease, but on the contrary 
- improve the quality of life in patients with bronchial asthma $[74,75,76]$ and concomitant obesity [77, 78].

Many studies show that walking, dancing, jogging, cycling, as well as static and dynamic gymnastics improve the course of the disease, improve the rates of external respiration, anxiety and depression at any stage of the disease $[79,80,81,82,83]$. The following sports have a particularly positive effect on asthma control: football, basketball, swimming [84], and in patients with "night" asthma aerobic exercise reduces the frequency of nocturnal symptoms in both adults and children [85], increases aerobic endurance [ 86], but do not affect the activity of airway inflammation $[87,88]$. However, a year later there was no significant difference in VO2 and ACQ (asthma control questionnaire) [89]. However, the fear of causing an asthma attack prevents many patients with bronchial asthma from fully exercising. Feshchenko YI. and sing. [90] believe that the most effective exercise is for patients with controlled disease.

Exercise (therapeutic exercise) for bronchial asthma is used at all stages of rehabilitation, which helps to normalize the function of external respiration. [74, 75]. It is a proven fact that in patients with bronchial asthma with reduced respiratory function, physical activity is maintained due to excessive activation of anaerobic metabolic processes and an increase in the energy value of the work performed. Therefore, rehabilitation measures should be aimed at increasing the motor activity of patients with bronchial asthma [1].

Regarding the intensity of exercise in bronchial asthma, there are some differences in the views of scientists. Russell M. et.al. [91] believe that less intense exercise gives a more positive result in bronchial asthma, while others - medium and high-intensity exercise give a worse result [88]. A long-term (12 years) study proved that the duration of daily physical activity (> $240 \mathrm{~min}$ ) визиває щорічно менше зниження $\mathrm{FEV}_{1}$ та FVC, чим у пацієнтів, фізична активність яких була $<240$ minutes per day [92].

There is evidence of a positive effect of breathing exercises in patients with bronchial asthma to improve quality of life $[93,94]$. Breathing exercises and yoga / pranayama play an additional role in the rehabilitation of asthma in children [95]. However, at present this cannot be recommended as a standard - due to insufficient data [96]. The same conclusions were reached by Santino T. et al. [97] analyzing 22 studies that examined the effects of methods Buteyko, Papworth, pranayama, deep diaphragmatic breathing in bronchial asthma. According to the GRADE criteria, the results ranged from moderate to very low efficiency. Further research is needed for definitive recommendations for the use of these methods in bronchial asthma. Interestingly, the emphasis on the effectiveness of work results changes over the years. In previous years, the Cochrane Review assessed lung function as a very important indicator of the outcome of the study, often with no data on quality of life or exacerbation of asthma. In recent studies, the opposite is true - the subjective results of the study are becoming increasingly important because it is most important for the patient [98].
Respiratory muscle training. An alternative to breathing exercises is to train the inspiratory muscles (BMI) to increase the strength and endurance of the diaphragm and the respiratory muscles. Inspiratory muscle training reduces shortness of breath, increases inspiratory force, reduces fatigue, and improves performance in patients with bronchial asthma $[99,100]$, and is more effective in combination with chiropractic and exercise [101]. Systematic reviews of the effectiveness of inspiratory muscle training in adults with bronchial asthma show that the evidence for its use has been inconclusive [102, 103].

Analyzing the Concran studies, Bruurs M. et al. [98] support the conclusions about the effectiveness of physical activity in bronchial asthma, but in recent years, in their opinion, the lack of work, which includes a combination of breathing, exercise and inspiratory muscle training, airway clearance. At the same time, there are difficulties in conducting a meta-analysis of methodological approaches. This means different methods of evaluating the results of efficiency, duration of exposure, and so on.

Barotherapy and endogenous training, positive respiratory pressure. Rehabilitation of patients with bronchial asthma at an altitude of $760-1300 \mathrm{~m}$, which included physical and respiratory exercises, the use of "endogenous-hypoxic" breathing in combination with cyclic exercises was effective in terms of spirography $[104,105]$, but there are insufficient randomized clinical trials would allow to have reasonable recommendations for the rehabilitation of patients with this pathology.

The use of positive airway pressure (CPAP therapy) reduced airway reactivity and nocturnal symptoms, decreased inflammatory activity, improved quality of life [106, 107], but in children within 4 weeks of moderate severe asthma on the methacholine test showed no effect [108]. CPAP therapy was effective in patients with bronchial asthma with obstructive sleep apnea-hypopnea syndrome: significantly reduced symptoms of asthma according to diaries of selfmonitoring control bronchial asthma (decrease in the questionnaire for control of bronchial asthma (ACQ), significantly increased the quality of life of patients).

For the treatment and rehabilitation of patients with bronchial asthma in Ukraine and neighboring countries are widely used therapeutic massage, preformed physical factors: magnetic therapy, electrophoresis, microwave and laser therapy. These factors stimulate blood and lymph circulation, increase nonspecific resistance, and in some cases act reflexively - relieving bronchospasm [7, 110, 111, 112]. However, there is no data from foreign authors on the effectiveness of these methods.

Bronchial thermoplasty is a relatively new nonpharmacological method of treatment and rehabilitation of patients with bronchial asthma, in which heat energy is supplied to the airways in a controlled way (endoscopically), using radiofrequency energy to reduce spasm of airway smooth muscle in patients with moderate cannot be controlled by drug therapy [113]. 
Psychological interventions. It is established that the use of relaxation methods significantly reduces the use of drugs and improves external respiration. Cognitive behavioral therapy significantly affects the quality of life, as measured by the appropriate questionnaire for asthmatics [114]. Psychological support should be especially in severe disease [115], and psychological training for parents whose children have asthma has been shown to be positive for both children and parents [116].

Educational programs. Therapeutic education of patients is aimed at helping them to acquire and maintain the necessary skills of self-management of their disease. The Cochrane Reviews reported a positive effect of patients' therapeutic education on asthma control, namely, reduction of symptoms at night, number of days of limited activity and improvement of quality of life, but the combined results were not statistically significant. It is believed that therapeutic education of patients is more effective in uncontrolled asthma, especially in children $[48,117,118]$, regardless of who conducts it (medical or social workers) [119]. The program "training-practicepersuasion" for children and parents proved to be effective [120]. However, it does not seem possible to identify the most effective therapeutic training programs for patients among more than 20 programs. Telemedicine training, written diaries for asthma self-monitoring (WAP) also reduce the risk of hospitalization, especially for patients with severe asthma [121, 122, 123], the best effect is achieved with multifaceted (combined) educational methods in primary care [124, 125].

\section{Discussion}

It is an indisputable fact that the elimination of allergens is important for the prevention and treatment of bronchial asthma, as allergic sensitization to pets, house dust mites in children with persistent asthma is $25-65 \%$, and to fungal allergens - in $76 \%$ of patients who repeatedly treated inpatiently, but it is believed that most species of fungi are not yet known. Interestingly, an association was found between fungal exposure and the risk of respiratory symptoms, regardless of sensitization status [14]. Experts from the US National Asthma and Asthma Prevention Education Program (NAEPP EPR-3) recommend a multifaceted, anti-allergenic approach to reducing the impact of indoor triggers, including new approaches to socalled "green" construction, and recommend research to identify early microbiome patterns human and its metabolism in the gastrointestinal tract, respiratory tract and skin, which are associated with the development of allergic diseases. [126]. New methods are currently being developed to control ticks, cockroaches, etc. Evidence from recent studies [27, 28, 30, 127] suggests that interventions aimed at eliminating a single allergen may be effective in reducing allergen levels and asthma incidence, and this approach deserves further study. Studies using personal monitoring devices for allergens, contaminants and microbes will be able to clarify the importance of environmental quality for the control of bronchial asthma [126].
It should be noted that there is currently no evidence that vaccination is effective in preventing bronchial asthma, but respiratory viruses exacerbate the disease [128] and GINA logically recommends influenza vaccination, although it has not been effective in combating asthma [3].

We must agree with the results of studies by Moreno-Macias H, Romieu I .. [129] that the appointment of antioxidants and vitamin supplements to reduce the risk of bronchial asthma should be considered in special situations, in particular in people with severe deficiency of these biologically active substances and the presence of provoking environmental factors. Many scientific studies have not found a significant effect of diet on the treatment and rehabilitation of bronchial asthma [40, 41, 42], but the role of vitamin $\mathrm{D}$ in prevention and rehabilitation requires additional research.

Another aspect is the role of probiotics in the prevention and rehabilitation of patients with bronchial asthma [130]. According to the recommendations of the World Allergy Organization (WAO), it is necessary to conduct randomized controlled trials of probiotics of specific strains, dosages and timing of use to provide clinical recommendations for asthma [131].

GINA recommends a healthy diet for this category of patients, although there is no evidence of specific dietary interventions for the prevention, treatment and rehabilitation of bronchial asthma, but there is strong evidence that overweight or obesity increase the risk of bronchial asthma in children and adults of both sexes [ 46 , 47, 48].

Phytotherapy is an important tool for primary health care in developing countries and currently in the world 11-40\% of asthmatics use herbal medicines [58]. Despite the widespread use of herbal medicine in the treatment of bronchial asthma [59, 60, 61], today there is not enough controlled randomized trials to recommend this method for widespread use and another issue that will not be solved in herbal medicine - is the dosage and variety of herbs in different countries used in treatment and prevention.

Studies on speleotherapy in bronchial asthma have shown a slight improvement in functional parameters, but currently available data do not allow us to reliably draw conclusions about the effectiveness of speleotherapy interventions for rehabilitation of patients with bronchial asthma [63], as in most cases, there was a comprehensive therapy component is difficult, and still - a small number of patients.

There are many unresolved issues in the use of acupuncture in this disease, despite the effective use of this method in the treatment of bronchial asthma for many years [68]. Lei-Miao Yin. et.al. [132] believe that the conclusions may be erroneous due to methodological inaccuracies: insufficient sample size to meet statistical requirements, poor reporting with missing information, subjective bias against acupuncture and incorrect control, and a multifaceted study is currently being conducted in China that aims to provide reliable clinical evidence of the effectiveness of acupuncture in the treatment of asthma. 
Our review revealed a significant improvement in quality of life and symptoms of the disease with increasing physical activity [76, 85, 133, 134], but there are still issues of dosage, duration, frequency of appointment. As the analysis showed, there is insufficient work on the effects of physiotherapy on children with asthma, while this is the group of patients in whom primarily

diagnose the disease. Exercise is an integral part of bronchial asthma rehabilitation. The mechanism of exercise is based on the restructuring of pathologically altered regulation of respiration, and in the process of systematic training, with a gradual increase in dosage of special and gymnastic exercises improve external respiration by increasing the diffusion surface of the lungs, mobilization of circulatory and in the fight against hypoxia. Normalization of gas exchange occurs due to the influence not only on external but also on tissue respiration $[7,90,135]$.

The use of breathing exercises is based on the fact that patients with asthma have a dysfunctional breathing structure and their task is to "normalize" breathing by reducing respiratory rate and reducing hyperventilation. Training also includes the promotion of nasal and diaphragmatic breathing. The results of the analysis did not show a significant effect in this pathology, but the Royal Dutch Society of Physiotherapy (KNGF) recommends breathing exercises (adult grade A) for adult patients [98].

It is safe to assume that increased respiratory muscle strength in people with asthma may reduce the intensity of shortness of breath and increase exercise tolerance, and it is possible that muscle loss, including respiratory muscle loss, occurs in patients treated with corticosteroids. The review showed that BMI reduces shortness of breath, increases inspiratory force, reduces fatigue, and improves performance in patients with bronchial asthma [99, 100], but there are insufficient studies and volume of subjects to recommend for use. The same opinion is held by Shei R. et al. [136] and recommend the development and testing of a standard treatment protocol in a large placebo-controlled, placebocontrolled clinical trial to develop more specific recommendations for BMI as an effective, low-cost adjunctive rehabilitation method for asthma patients. Analyzing the Concran studies, Bruurs M. et al. [98] support the conclusions about the effectiveness of physical activity in bronchial asthma, but in recent years, in their opinion, the lack of work, which includes a combination of breathing, exercise and BMI, airway clearance. At the same time, there are difficulties in conducting a metaanalysis of methodological approaches. This means different methods of evaluating the results of efficiency, duration of exposure, and so on

Barotherapy and endogenous training, positive respiratory pressure. Despite the positive results of research, there are insufficient randomized clinical trials that would allow to have reasonable recommendations for the rehabilitation of patients with this pathology.

Bronchial thermoplasty is a relatively new method of treating bronchial asthma, but is unlikely to be widely used, as it is invasive.

Psychological and educational programs. The recommendations of international organizations, including GINA, clearly emphasize the importance of education for patients with bronchial asthma to acquire asthma management skills. Our review confirms that therapeutic training programs for patients significantly improve asthma control [117, 118]. But as most scientists point out, a program focused on various factors in the fight against asthma is needed, similar to the coordinated French program EPODE, aimed at reducing childhood obesity [125].

\section{Conclusions}

Non-drug methods of prevention and rehabilitation are widely used (as additional) in bronchial asthma. Among them, phytotherapy, acupuncture, exercise, breathing exercises have proved to be the most effective, and the search for different types of diet therapy continues. Despite many years of application of these methods, so far there are no clear recommendations: indications, dosage, duration, frequency. Educational and self-monitoring programs have proved to be effective, but many of them are not standardized and therefore there are difficulties in their use.

\section{Conflict of interest}

Authors state that there is no conflict of interest.

\section{References}

1. Feshchenko YuI. Novi pidkhody pokrashchennia likuvannia bronkhialnoi astmy u svitovii praktytsi. Materialy konferentsii. Asthma and Allergy. 4. 2019.

2. To T, Stanojevic S, Moores G. et al. . Global asthma prevalence in adults: findings from the cross-sectional world health survey. BMC Public Health. 2012;12:204.

3. Global Initiative for Asthma. Global Strategy for Asthma Management and Prevention, Update 2019. Available from: www.ginasthma.org.
4. Maas T, Dompeling E, Muris J, Wesseling G, Knottnerus J, van Schayck OC. Prevention of asthma in genetically susceptible children: a multifaceted intervention trial focussed on feasibility in general practice. Pediatr Allergy Immunol 2011;22(8):794802.

5. Ricklefs Isabell, Hohmann-Ebbers Michelle, Herz Alexander, Kopp Matthias V. Use of Complementary 
and Alternative Medicine in Children With Asthma. Pediatr Allergy Immunol.2018;29 (3):326-328.

6. Hryhus IM. Fizychna reabilitatsiia khvorykh na bronkhialnu astmu: monohrafiia. - Saarbrücken : LAMBERT Academic Publishing, 2017.278 s.

7. Dykyi BV, Rostoka-Reznikova BV. Nemedykamentozni metody $\mathrm{v}$ reabilitatsii khvorykh na bronkhialnu astmu. Uzhhorod, 2013.37 s.

8. Fawad Ahmed, Ayaz Ayub, Hamid Hussain. Use Of Complementary And Alternative Medicine Among Asthmatic Patients. J Ayub Med Coll Abbottabad.2017;29 (2):298-302.

9. Kam Lun Hon, Yan Min Bao, Kate C Chan, Kin Wai Chau. Determinants for Asthma Control, Quality of Life and Use of Complementary and Alternative Medicine in Asthmatic Pediatric Patients in Four Cities. World J Pediatr. 2018;14(5):482-491. DOI: $10.1007 / \mathrm{s} 12519-018-0167-1$

10.Maureen George, Topaz Maxim. A Systematic Review of Complementary and Alternative Medicine for Asthma Self-management. Nurs Clin North Am. 2013 Mar;

0.1016/j.cnur.2012.11.002. doi: 10.1016/j.cnur.2012.1 1.002 .

11. Ahluwalia SK, Peng RD, Breysse PN, Diette GB, Curtin-Brosnan $\mathrm{J}$, Aloe $\mathrm{C}$, et al. Mouse allergen is the major allergen of public health relevance in Baltimore City. Journal of Allergy and Clinical Immunology. 2013;132(4):830-5.

12. Gruchalla RS, Pongracic J, Plaut M, Evans R, Visness CM, Walter $\mathrm{M}$, et al. Inner City Asthma Study: relationships among sensitivity, allergen exposure, and asthma morbidity. J Allergy Clin Immunol. 2015;115(3):476-85.

13. Zaikov SV, Umanets TR, Kasianenko HV. Rol эlymynatsyonnыkh meropryiatyi v lechenyy patsyentov s allerhycheskymy zabolevanyiamy. Astma ta Alerhiia. 2019;3: 41-55. DOI: 10.31655/2307-33732019-3-41-55

14. Ahluwalia SK, Matsui EC. Indoor Environmental Interventions for Furry Pet Allergens, Pest Allergens, and Mold: Looking to the Future.J Allergy Clin Immunol Pract. 2018 Jan - Feb;6(1):9-19. doi: 10.1016/j.jaip.2017.10.009.

15. Matsui EC, Abramson SL, Sandel. Indoor Environmental Control Practices and Asthma ManagementPediatrics. 2016 Nov;138(5). pii: e20162589.

16. Junenette L, Peters, Sheldon Cohen, John Staudenmayer, Jacob Hosen, Thomas AE, et.al. Prenatal negative life events increases cord blood IgE: Interactions with dust mite allergen and maternal atopy
Allergy. $2012 \quad$ Apr; $67(4): \quad$ 545-551. doi: 10.1111/j.1398-9995.2012.02791.x.

17. Scott M, Roberts G, Kurukulaaratchy RJ, Matthews S, Nove A, Arshad SH. Multifaceted allergen avoidance during infancy reduces asthma during childhood with the effect persisting until age 18 years. Thorax. 2012 Dec;67(12):1046-51. doi: 10.1136/thoraxjnl-2012-202150.

18. Esty B, Permaul P, DeLoreto K, Baxi SN, Phipatanakul W. Asthma and Allergies in the School Environment. Clin Rev Allergy Immunol. 2019 Dec;57(3):415-426. doi: 10.1007/s12016-019-08735y.

19. Sauni R, Uitti J, Jauhiainen M, et al. Remediating buildings damaged by dampness and mould for preventing or reducing respiratory tract symptoms, infections and asthma (Review). Evid Based Child Health. 2013;8:944-100.

20. Sheehan WJ, Permaul P, Petty CR, Coull BA, Baxi SN, Gaffin JM, et.al. Association Between Allergen Exposure in Inner-City Schools and Asthma Morbidity Among Students. JAMA Pediatr. 2017 Jan $1 ; 171(1): 31-38$.

doi: 10.1001/jamapediatrics.2016.2543.

21. Blackhall K, Appleton S, Cates CJ. Ionisers for chronic asthma. Cochrane Database Syst Rev. 2012;9:CD002986

22. Singh M, Jaiswal N. Dehumidifiers for chronic asthma. Cochrane Database Syst Rev. 2013;6:CD003563.

23. Jackson DJ, Sykes A, Mallia P, Johnston SL. Asthma exacerbations: origin, effect, and prevention. J Allergy Clinical Immunol. 2011;128:1165-1174.

24. De Groene GJ, Pal TM, Beach J. Workplace interventions for treatment of occupational asthma: a Cochrane systematic review. Occup Environ Med. 2012;69:373-374.

25. Henneberger PK, Patel JR, de Groene GJ, Beach J, Tarlo SM, Pal TM, Curti S. Workplace interventions for treatment of occupational asthma. Cochrane Database Syst Rev. 2019 Oct 8;10:CD006308. doi: 10.1002/14651858.CD006308.pub4.

26. El-Ghitany EM, Abd El-Salam MM. Environmental intervention for house dust mite control in childhood bronchial asthma. Environ Health Prev Med. 2012 Sep;17(5):377-84.

27. Xiang L, Fu Y, Wang J, Wang Q.The correlation between the seasonal variation of house dust mite allergens exposure level in household and the level of asthma control in asthmatic children. Zhonghua Er Ke Za Zhi. 2014 Mar;52(3):177-83. 
28. DiMango E, Serebrisky D, Naurla S, Shim C, Keating $\mathrm{C}$, Sheares B, et al. Individualized household allergen intervention lowers allergen level but not asthma medication use: A randomized controlled trial. J Allergy Clin Immunol Pract. 2016;4(4):671-9.

29. Matsui EC, Perzanowski M, Peng RD, et al. Effect of an integrated pest management intervention on asthma symptoms among mouse-sensitized children, adolescents with asthma: a randomized control trial. JAMA. 2017;317(10):1027-36.

30. Gergen PJ, Mitchell HE, Calatroni A, Sever ML, Cohn RD, Salo PM, et al. Sensitization and Exposure to Pets: The Effect on Asthma Morbidity in the US Population. J Allergy Clin Immunol Pract. 2017 Jul 08; epub ahead of print.

31. Glasgow NJ, Ponsonby A-L, Kemp A, et al. Feather bedding and childhood asthma associated with house dust mite sensitisation: a randomised controlled trial. Arch Dis Child. 2011;96:541-547.

32. Wang J, Wang Q. The correlation between the seasonal variation of house dust mite allergens exposure level in household and the level of asthma control in asthmatic children. Zhonghua Er Ke Za Zhi. 2014 Mar;52(3):177-83.

33. Rabito FA, Carlson JC, He H, Werthmann D, Schal C. A single intervention for cockroach control reduces cockroach exposure and asthma morbidity in children. J Allergy Clin Immunol. 2017 Aug;140(2):565-570. doi: 10.1016/j.jaci.2016.10.019.

34. Lodrup Carlsen KC, Roll S, Carlsen K, Mowinckel P, Wijga A, Brunekreef B, et al. Does pet ownership in infancy lead to asthma or allergy at school age? Pooled analysis of individual participant data from 11 European birth cohorts. PLoS ONE 2012;7(8):e43214.

35. Kennedy S, Bailey R, Jaffee K, et al. Effectiveness of evidence-based asthma interventions. Pediatrics. 2017;139(6): e20164221.

36. Leas BF, D'Anci KE, Apter AJ, Bryant-Stephens T, Lynch MP, Kaczmarek JL, et al. Effectiveness of Indoor Allergen Reduction in the Management of Asthma: A Systematic Review. J Allergy Clin.Immunol 2018;13:1.

37. Kalaci O, Giangioppo S, Leung G, Radhakrishnan A, Fleischer E, Lyttle B, Price, et al. Complementary and alternative medicine use in children with asthma. Complement Ther Clin Pract. 2019 May;35:272-277. doi: 10.1016/j.ctcp.2019.02.017.

38. SIGN158. British guideline on the management of asthma. A national clinical guideline First published 2003.Revised edition published July 2019.

39. Cates CJ, Rowe BH. Vaccines for preventing influenza in people with asthma. Cochrane Database Syst Rev. 2013;2:CD000364.
40.40.Kaur B, Rowe BH, Stovold E. Vitamin C supplementation for asthma. Cochrane Database Syst Rev. 2013;3:CD000993.

41. Pogson Z, McKeever T. Dietary sodium manipulation and asthma. Cochrane Database Syst Rev. 2011;3:CD000436.

42. Zhou Y, Yang M, Dong BR. Monosodium glutamate avoidance for chronic asthma in adults and children. Cochrane Database Syst Rev. 2012;6:CD004357.

43. Tarazona-Meza CE, Hanson C, Pollard SL, Romero Rivero KM, Galvez Davila RM, Talegawkar S, et.al. Dietary patterns and asthma among Peruvian children and adolescents. BMC Pulm Med. 2020 Mar 14;20(1):63. doi: 10.1186/s12890-020-1087-0.

44. Abuabat F, Alwan A, Masuadi E, Murad MH, Jahdali HA, Ferwana MS. The role of oral magnesium supplements for the management of stable bronchial asthma: a systematic review and metaanalysis. NPJ Prim Care Respir Med. 2019 Feb 18;29(1):4. doi: 10.1038/s41533-019-0116-z.

45. Adeniyi FB, Young T. Weight loss interventions for chronic asthma. Cochrane Database Syst Rev. 2012;7:CD009339

46. Chen YC, Dong GH, Lin KC, Lee YL. Gender difference of childhood overweight and obesity in predicting the risk of incident asthma: a systematic review and meta-analysis. Obes Rev. 2013;14(3):22231.

47. Egan KB, Ettinger AS, Bracken MB, Egan KB, Ettinger AS, Bracken MB. Childhood body mass index and subsequent physician-diagnosed asthma: a systematic review and meta-analysis of prospective cohort studies. BMC Pediatr 2013;13:1.

48. Farag H, Abd El-Wahab EW, El-Nimr NA, Saad ElDin HA. Asthma action plan for proactive bronchial asthma self-management in adults: a randomized controlled trial. Int Health. 2018 Nov 1;10(6):502-516. doi: 10.1093/inthealth/ihy050.

49. McEvoy CT, Schilling D, Clay N, Jackson K, Go MD, Spitale P, et.al. Vitamin C supplementation for pregnant smoking women and pulmonary function in their newborn infants: a randomized clinical trial. JAMA. 2014 May;311(20):2074-82. doi: 10.1001/jama.2014.5217.

50. Martineau AR, Cates CJ, Urashima M, Jensen M, Griffiths AP, Nurmatov U, et al. Vitamin D for the management of asthma. Cochrane Database of Systematic Reviews 2016: Issue 9.

51. Litonjua AA, Carey VJ, Laranjo N, Harshfield BJ, McElrath TF, O'Connor GT, et.al. Effect of Prenatal Supplementation With Vitamin D on Asthma or Recurrent Wheezing in Offspring by Age 3 Years: 
The VDAART Randomized Clinical Trial. JAMA. 2016 Jan 26;315(4):362-70. doi: 10.1001/jama.2015.18589.

52. Thorsteinsdottir F, Cardoso I, Keller A, Stougaard M, Frederiksen P, Cohen AS, et.al. Neonatal Vitamin D Status and Risk of Asthma in Childhood: Results from the D-Tect Study. Nutrients. 2020 Mar 21;12(3). pii: E842. doi: 10.3390/nu12030842204.

53. Azimzadeh Jamalkandi S, Ahmadi A, Ahrari I' Salimian J, Karimi M, Ghanei M. Oral and nasal probiotic administration for the prevention and alleviation of allergic diseases, asthma, and COPD. Nutr Res Rev. 2020 Apr 13:1-34. doi: 10.1017/S0954422420000116.

54. Wang W, Luo X, Zhang Q, He X, Zhang Z, Wang X. Bifidobacterium infantis Relieves Allergic Asthma in Mice by Regulating Th1/Th2. Med Sci Monit. 2020 Apr 6;26:e920583. doi: 10.12659/MSM.920583.

55. Cabana MD, McKean M, Caughey AB, Fong L, Lynch S, Wong A, et.al. Early Probiotic Supplementation for Eczema and Asthma Prevention: A Randomized Controlled Trial. Pediatrics. 2017 Sep;140(3). pii: e20163000. doi: 10.1542/peds.20163000 .

56. Zainab R, Akram M, Daniyal M, Riaz M. Awareness and Current Therapeutics of Asthma. Dose Response. 2019 Sep 4;17(3):1559325819870900. doi: $10.1177 / 1559325819870900$.

57. Fouladi S, Masjedi M, Ganjalikhani Hakemi M, Eskandari N. The Review of in Vitro and in Vivo Studies over the Glycyrrhizic Acid as Natural Remedy Option for Treatment of Allergic Asthma. Iran J Allergy Asthma Immunol.2019 Feb;18(1):1-11.

58. Abidi Afroz, Surabhi Gupta, Manu Agarwal, HL. Bhalla, Mahip Saluja. Evaluation of Efficacy of Curcumin as an Add-on therapy in Patients of Bronchial AsthmaJ Clin Diagn Res. 2014 Aug; 8(8): HC19-HC24. doi: 10.7860/JCDR/2014/9273.4705.

59. Amaral-Machado L, Oliveira WN, Moreira-Oliveira SS, Pereira DT, Alencar ÉN, Tsapis N, et.al. Use of Natural Products in Asthma Treatment. Evid Based Complement Alternat Med. $2020 \quad$ Feb 13;2020:1021258. doi: 10.1155/2020/1021258.

60. Sabarathinam Sarvesh, Mathivanan Koushik Muthu Raja, Muhasaparur Ganesan Rajanandh, Palanichamy Seenivasan. Prevalence and Pattern of Usage of Complementary and Alternative Medicine Among South Indian Asthma Patients in a Tertiary Care Hospital. Complement Ther Clin Pract. 2018;30:103108. DOI: 10.1016/j.ctcp.2017.12.016.

61. Shergis JL, Wu L, Zhang AL, Guo X, Lu C, Xue CC. Herbal medicine for adults with asthma: A systematic review. J Asthma. 2016 Aug;53(6):650-9. doi: 10.3109/02770903.2015.1101473.

62. Horbenko VP, Horbenko PP, Horbenko KP. Speleoterapiia V solianykh kopalniakh - osnova tekhnolohii haloterapii ta haloozdorovlennia. Astma ta alerhiia. 2018;2:48-49.

63. Galamba AA, Tovt-Korshyns'ka MI, RostokaReznikova MV, Sukhan VS, Dychka LV. Rehabilitation features in the prevention of asthma exacerbations in patients with different body weight. Wiad Lek. 2014;67(2 Pt 2):173-5.

64. Lăzărescu H, Simionca I, Hoteteu M, Mirescu L. Speleotherapy - modern bio-medical perspectives. J Med Life. 2014;7(2):76-9.

65. Airrapetova NS, Rassulova MA, Antonovich IV, Stiazhkina EM, Ksenofontova IV, Nikoda NV, et.al. The rationale for the combined application of cryomassage and silvinite speleotherapy for the rehabilitative treatment of the patients with bronchial asthma. Vopr Kurortol Fizioter Lech Fiz Kult.2011Sep-Oct;(5):12-7.

66. Symulyk VD, Bilak VM, Tomei AI. Efektyvnist povtornykh kursiv likuvannia metodom speleoterapii ditei, khvorykh na bronkhialnu astmu. Problemy klinichnoi pediatrii . 2016;1-2:69-76.

67. Network BTSSIG. British guideline on the management of asthma. Thorax. 2014;69:i1.

68. Yang YQ, Chen HP, Wang Y, Yin LM, Xu YD, Ran J. Considerations for use of acupuncture as supplemental therapy for patients with allergic asthma. Clin Rev Allergy Immunol. 2013;44:254-61. doi: 10.1007/s12016-012-8321-3.

69. Shen FY, Lee MS, Jung SK. Effectiveness of pharmacopuncture for asthma: a systematic review and meta-analysis. Evid Based Complement Alternat Med. 2011;2011:678176.

70. McCormick S, Nezu C. Coping and social problem solving correlates of asthma control and quality of life. Chronic Respiratory Disease. 2014;11:15-21.

71. Ding S, Zhong C. Exercise and Asthma. Adv Exp Med Biol. 2020;1228:369-380. doi: 10.1007/978-981-151792-1_25.

72. Jaakkola MS, Aalto SAM, Hyrkäs-Palmu H, Jaakkola JJK. Association between regular exercise and asthma control among adults: The population-based

Finnish Asthma Study.PLoS One. $2020 \quad$ Jan 23;15(1):e0227983. doi: 10.1371/journal.pone.0227983.

73. Eijkemans M, Mommers M, Remmers T, Draaisma JMT, Prins MH, Thijs C. Physical activity and asthma development in childhood: Prospective 
birth cohort study.Pediatr Pulmonol. 2020 Jan;55(1):76-82. doi: 10.1002/ppul.24531.

74. Beggs S, Foong YC, Le HCT. Swimming training for asthma in children and adolescents aged 18 years and under. Cochrane Database Syst Rev. 2013;4:CD009607.

75. Chandratilleke MG, Carson KV, Picot J, et al. Physical training for asthma. Cochrane Database Syst Rev. 2012;5:CD001116.

76. Sousa AW, Cabral ALB, Martins MA, Carvalho CRF. Barriers to daily life physical activities for Brazilian children with asthma: a cross-sectional study. J Asthma. 2019 Mar 28:1-9. doi: 10.1080/02770903.2019.1594249.

77. Türk Y, Theel W, van Huisstede A, van de Geijn GM, Birnie E, Hiemstra PS, et.al. Short-term and long-term effect of a high intensity pulmonary rehabilitation program in obese patients with asthma: a randomised controlled trial.Eur Respir J. 2020 Apr 16. pii: 1901820. doi: 10.1183/13993003.01820-2019.

78. Rodrigues A, de Oliveira JM, Furlanetto KC, Machado FVC, Belo LF, Schneider LP, et.al. Are the Effects of High-Intensity Exercise Training Different in Patients with COPD Versus COPD+Asthma Overlap? Lung. 2020 Feb;198(1):135-141. doi: 10.1007/s00408-019-003117.

79. Petrenko LV, Pokropyvnyi OM. Bronkhialna astma: prohrama reabilitatsii. Aktualni problemy klinichnoi ta profilaktychnoi medytsyny. 2016;4(1):42-45.

80. Khrystova TIe. Kompleksna fizychna reabilitatsiia ditei, khvorykh bronkhialnoiu astmoiu. XV1 Mizhnarodna naukovo-praktychna konferentsiia. Fizychna kultura, sport ta zdoroviaia. 2016. 296-299.

81. Freitas Diana A, Holloway Elizabeth A, Bruno Selma S, Chaves Gabriela SS, Fregonezi Guilherme AF, Mendonзa Karla MPP. Breathing exercises for adults with asthma. Cochrane Database of Systematic Reviews 2013:doi.org.10.1002/14651858.CD001277.pub.3.

82. Zhang W, Wang Q, Liu L, Yang W, Liu H. Effects of physical therapy on lung function in children with asthma: a systematic review and meta-analysis. Pediatr Res. 2020 Apr 3. doi: 10.1038/s41390-0200874-x.

83. Zampogna E, Spanevello A, Visca D. Pulmonary rehabilitation: promising nonpharmacological approach for treating asthma? Curr Opin Allergy Clin Immunol. 2020 Feb;20(1):8084. doi: 10.1097/ACI.0000000000000597.

84. Carew C, Cox DW. Laps or lengths? The effects of different exercise programs on asthma control in children. J Asthma. 2018 Aug;55(8):877-881. doi: 10.1080/02770903.2017.1373806.

85. Francisco CO, Bhatawadekar SA, Babineau J, Reid WD, Yadollahi A. Effects of physical exercise training on nocturnal symptoms in asthma: Systematic review. PLoS One. 2018 Oct 22;13(10):e0204953. doi: 10.1371/journal.pone.0204953.

86. $\mathrm{Lu} \mathrm{KD,} \mathrm{Forno} \mathrm{E.} \mathrm{Exercise} \mathrm{and} \mathrm{lifestyle} \mathrm{changes} \mathrm{in}$ pediatric asthma. Curr Opin Pulm Med. 2020 Jan;26(1):103-111.

doi: 10.1097/MCP.0000000000000636.

87. Hansen ESH, Pitzner-Fabricius A, Toennesen LL, Rasmusen HK, Hostrup M, Hellsten Y, et.al. Effect of aerobic exercise training on asthma in adults - A systematic review and meta-analysis. Eur Respir J. 2020 Apr 29. pii: 2000146 doi: 10.1183/13993003.00146-2020.

88. Pitzner-Fabricius A, Toennesen LL, Backer V. Can training induce inflammatory control in asthma, or is it symptom control only? Curr Opin Pulm Med. 2020 Jan;26(1):56-61.

doi: 10.1097/MCP.0000000000000648.

89. Bentzon AK, Loehde LW, Backer V, Toennesen L.The long-term effect of an exercise and diet intervention in asthma patients: a 1-year follow-up on a randomised controlled trial. ERJ Open Res. 2019 Jun 24;5(2). pii: 00032-2019. doi: 10.1183/23120541.00032-2019.

90. Feshchenko YuY, Kuryk LM, Kanarskyi AA, Turchyna YP. Fyzycheskaia aktyvnost bolnыkh bronkhyalnoi astmoi $\mathrm{V}$ zavysymosty ot kontrolyruemosty techenyia zabolevanyia. Ukr.pulmon.zhurnal.2019;4:5-10.

91. Russell MA, Janson C, Real FG, Johannessen A, Waatevik M, Benediktsdóttir B, et.al. Physical activity and asthma: A longitudinal and multi-country study. J Asthma. 2017 Nov;54(9):938-945. doi: 10.1080/02770903.2017.1281293.

92. Loponen J, Ilmarinen P, Tuomisto LE, Niemelä O, Tommola M, Nieminen P, et.al. Daily physical activity and lung function decline in adult-onset asthma: a 12-year follow-up study. Eur Clin Respir J. 2018 Oct 24;5(1):1533753. doi: $10.1080 / 20018525.2018 .1533753$.

93. Hryhus IM, Ryhun MH. Efektyvnist zastosuvannia kompleksnoi prohramy fizychnoi reabilitatsii khvorykh na bronkhialnu astmu. Reabilitatsiini ta fizkulturno-rekreatsiini aspekty rozvytku liudyny (Rehabilitation \& recreation) : naukovyi zhurnal. Rivne : NUVHP, 2018;3:21-27.

94. Burgess J, Ekanayake B, Lowe A, Dunt D, Thien F, Dharmage SC. Systematic review of the effectiveness of breathing retraining 
in asthma management. Expert Rev Respir Med. 2011 Dec;5(6):789-807. doi: 10.1586/ers.11.69.

95. Erdoğan Yüce G, Taşcı S. Effect of pranayama breathing technique $\mathrm{n}$ asthma control, pulmonary function, and quality of life: A single-blind, randomized, controlled trial. Complement Ther Clin Pract. $2020 \quad$ Feb;38:101081. doi: 10.1016/j.ctcp.2019.101081.

96. Rashmi Ranjan Das, Jhuma Sankar, Sushil Kumar Kabra. Role of Breathing Exercises and Yoga/Pranayama in Childhood Asthma: A Systematic Review. Curr Pediatr Rev. 2019;15 (3):175-183.

97. Santino TA, Chaves GS, Freitas DA, Fregonezi GA, Mendonça KM. Breathing exercises for adults with asthma. Cochrane Database Syst Rev. 2020 Mar 25;3:CD001277. doi: 10.1002/14651858.CD001277.pub4.

98. Bruurs ML, van der Giessen LJ, Moed H. The effectiveness of physiotherapy in patients with asthma: a systematic review of the literature. Respir Med. 2013 Apr;107(4):483-94. doi: 10.1016/j.rmed.2012.12.017.

99. Duruturk N, Acar M, Doğrul MI. Effect of Inspiratory Muscle Training in the Management of Patients With Asthma: A randomized controlled trial. J Cardiopulm Rehabil Prev. 2018 May;38(3):198-203. doi: 10.1097/HCR.0000000000000318.

100. Göhl O, Walker DJ, Walterspacher S, Langer D, Spengler CM, Wanke T, et.al. Respiratory Muscle Training: State of the Art.Pneumologie. 2016 Jan;70(1):37-48. doi: 10.1055/s-0041-109312.

101. López-de-Uralde-Villanueva I, CandelasFernández $\mathrm{P}$, de-Diego-Cano $\mathrm{B}$, Mínguez-Calzada O, Del Corral T. The effectiveness of combining inspiratory muscle training with manual therapy and a therapeutic exercise program on maximum inspiratory pressure in adults with asthma: a randomized clinical trial. Clin Rehabil. 2018 Jun;32(6):752-765. doi: $10.1177 / 0269215517751587$.

102. Bruton A, Lee A, Yardley L, Raftery J, ArdenClose E, Kirby S, et al. Physiotherapy breathing retraining for asthma: a randomised controlled trial. Lancet. Respir Med.2018;6(1):19-28.

103. Prem V, Sahoo RC, Adhikari P. Comparison of the effects of Buteyko and pranayama breathing techniques on quality of life in patients with asthma - a randomized controlled trial. Clin Rehabil.2013;27(2):133-41.

104. Onyshchuk VE, Furman YuM. Ekspres-vplyv «endohenno-hipoksychnoho» dykhannia ta fizychnoho navantazhennia na pokaznyky spirohrafii u khvorykh na bronkhialnu astmu. Visnyk Zaporizkoho natsionalnoho universytetu. 2010;(3):176-179.
105. 105.Saxer S, Schneider SR, Appenzeller P, Bader PR. et.al. Asthma rehabilitation at high vs. low altitude: randomized parallel-group trial. BMC Pulm Med. 2019 Jul 24;19(1):134. doi: 10.1186/s12890-019-0890-y.

106. Busk M, Busk N, Puntenney P, Hutchins J, Yu Z, Gunst SJ, et.al. Use of continuous positive airway pressure reduces airway reactivity in adults with asthma.Eur Respir J. 2013 Feb;41(2):317-22. doi: 10.1183/09031936.00059712.

107. David MMC, Gomes ELFD, Mello MC, Costa D. Noninvasive ventilation and respiratory physical therapy reduce exercise-induced bronchospasm and pulmonary inflammation in children with asthma: randomized clinical trial. Ther Adv Respir Dis. 2018 Jan-Dec;12:1753466618777723. doi: $10.1177 / 17534666187777$.

108. Praca Eduardo, Hasnaa Jalou, Nadia Krupp, Angela Delecaris, Joseph Hatch, James Slaven, et.al. Effect of CPAP on Airway Reactivity and Airway Inflammation in Children With ModerateSevere Asthma Respirology,2019;24 (4):338-344.

109. Feshchenko YuI, Yashyna LO, Ihnatieva VI, Zvol IV, Opimakh SH, Polianska MO, i in. Nemedykamentozni mozhlyvosti pokrashchannia kontroliu astmy u patsiientiv iz suputnim syndromom obstruktyvnoho apnoe-hipopnoe snu. Ukr.pulmonol. zhurnal. 2016;3:24-29.

110. Hryhus I. Rol fizychnoi aktyvnosti v reabilitatsii khvorykh, shcho strazhdaiut na lehku stiiku bronkhialnu astmu.Fizychne vykhovannia, kultura sportu ta zdorovia $\mathrm{v}$ suchasnomu suspilstvi.2017;2(38):140-150. doi.org/10.29038/2220-7481-2017-02-140-150.

111. Pieshkova OV, Avramenko OM, Mitko OV, Tretiak LO. Kompleksna fizychna reabilitatsiia ditei pry bronkhialnii astmi 11 stupenia tiazhkosti na statsionarnomu etapi. Slobozhanskyi naukovosportyvnyi visnyk. 2013;2:137.

112. Chuntyzheva EH, Uriasev OM, Korshunova LV, Ysaeva YA. Fyzycheskye metodы terapyy v lehochnoi reabylytatsyy bolnыkh s professyonalnoi bronkhyalnoi astmoi. Sovremennye problemy nauky y obrazovanyia 2017.5 .

113. Yaşar Z, Çetinkaya E. Bronchial thermoplasty; a new treatment modality in asthma. Tuberk Toraks. 2014;62(4):291-300.

114. Pourdowlat G, Hejrati R, Lookzadeh S. The effectiveness of relaxation training in the quality of life and anxiety of patients with asthma. Adv Respir Med. 2019;87(3):146-151. doi: 10.5603/ARM.2019.0024 
115. Apps LD, Chantrell S, Majd S, Eglinton E, Singh SJ, Murphy AC, et.al. Patient Perceptions of Living with Severe Asthma: Challenges to Effective Management. J Allergy Clin Immunol Pract. 2019 Nov - Dec;7(8):2613-2621.e1. doi: 10.1016/j.jaip.2019.04.026.

116. Chong, Y-Y, Leung D, Mak Y-W. When Control Exacerbates Distress: A Qualitative Study Exploring the Experiences of Hong Kong Chinese Parents in Caring for a Child with Asthma. Int. J. Environ. Res. Public Health. 2018;15(7):1372. https: doi.org/10.3390/ijerph15071372.

117. Guarnaccia S, Quecchia C, Festa A, Magoni M, Zanardini E, Brivio V, et.al. Evaluation of a DiagnosticTherapeutic Educational Pathway for Asthma Management in Children and Adolescents. Front Pediatr. 2020 Mar 11;8:39. doi: 10.3389/fped.2020.00039.

118. Peytremann-Bridevaux I, Arditi C, Gex G, et al. . Chronic disease management programmes for adults with asthma. Cochrane Database Syst Rev. 2015;5.CD007988.

119. Baishnab E, Karner C. Primary care based clinics for asthma. Cochrane Database Syst Rev. 2012;4:CD003533.

120. Lin HH, Hung YP, Weng SH, Lee PY, Sun WZ. Effects of parent-based social media and moderate exercise on the adherence and pulmonary functions among asthmatic children.2020 Jan;36(1):62-70. doi: 10.1002/kjm2.12126.

121. de Jongh T, Gurol-Urganci I, Vodopivec-Jamsek $\mathrm{V}$, et al. Mobile phone messaging for facilitating selfmanagement of long-term illnesses. Cochrane Database Syst Rev. 2012;12CD007459.

122. Marcano Belisario JS, Huckvale K, Greenfield G, et al. Smartphone and tablet self management apps for asthma. Cochrane Database Syst Rev. 2013;11.CD010013.

123. McLean S, Chandler D, Nurmatov $\mathrm{U}$, et al. Telehealthcare for asthma: a Cochrane review. CMAJ. 2011;183:E733-742.

124. Halterman JS, Fagnano M, Tremblay PJ, et al. Prompting asthma intervention in Rochester-uniting parents and providers (PAIR-UP): a randomized trial. JAMA Pediatr. 2014;168:e141983.

125. Schuers M, Chapron A, Guihard H, Bouchez T, Darmon D. Impact of non-drug therapies on asthma control: A systematic review of the literature. Eur J Gen Pract. 2019 Apr;25(2):65-76. doi: 10.1080/13814788.2019.1574742.

126. Gold D, Adamkiewicz G, Arshad SH, et al. . NIAID, NIEHS, NHLBI, MCAN Workshop Report: the indoor environment and childhood asthma: implications for home environmental intervention in asthma prevention and management. J Allergy Clinical Immunol. 2017;140:933-949.

127. Le Cann P, Paulus H, Glorennec P, Le Bot B, Frain S, Gangneux JP, et al. Home Environmental Interventions for the Prevention or Control of Allergic and Respiratory Diseases: What Really Works. J Allergy Clin Immunol Pract. 2017;5:66-79.

128. Busse WW, Lemanske RF, Gern JE. The role of viral respiratory infections in asthma and asthma exacerbations. Lancet. 2010;376:826-834.

129. Moreno-Macias H, Romieu I. Effects of antioxidant supplements and nutrients on patients with asthma and allergies. J Allergy Clin Immunol. 2014 May;133(5):1237-44; quiz $1245 . \quad$ doi: 10.1016/j.jaci.2014.03.020.

130. Huang L, Guo J, Li W, Jiang M, Wang F, Kang J, et.al. Probiotics, prebiotics, and synbiotics for the treatment of asthma: Protocol for a systematic review.Medicine (Baltimore). 2019 Nov;98(47):e17840 doi: 10.1097/MD.000000000001784.

131. West CE. Probiotics for allergy prevention. Benef Microbes. 2016;7(2):171-9. doi: 10.3920/BM2015.0073.

132. Yin Lei-Miao, Yu Wang, Lei Fan, Yu-Dong $\mathrm{Xu}$, Wen-Qian Wang, Yan-Yan Liu, et.al.Efficacy of acupuncture for chronic asthma: study protocol for a randomized controlled trial Trials.2015; 16: 424. doi: 10.1186/s13063-015-0947-Z

133. Heikkinen SAM, Mäkikyrö EMS, Hugg TT, Jaakkola MS, Jaakkola JJK, Effects of regular exercise on asthma control in young adults. Journal of Asthma Volume.2018;55(7):726-733 doi.org/10.1080/02770903.2017.1366510.

134. Jaakkola JJK, Aalto SAM, Hernberg S, Kiihamäki

SP.Regular exercise improves asthma control in adults: A randomized controlled trial. Sci Rep. 2019 Aug 19;9(1):12088. doi: 10.1038/s41598-019-484848.

135. Reheda MS, Reheda MM, Furdychko LO, Kolishetska MA, Myronenko SI. Bronkhialna astma. Monohrafiia. Vyd. piate, dop. ta perer. Lviv, $2012 ; 147 \mathrm{~s}$

136. Shei RJ, Paris HL, Wilhite DP, Chapman RF, Mickleborough TD. The role of inspiratory muscle training in the management of asthma and exerciseinduced bronchoconstriction. Phys Sportsmed. 2016 Nov;44(4):327-334 


\section{Information about the authors}

\section{Mytskan B.M.}

bogomdan_21@ukr.net http://orsid.org/0000-0002-5853-713X

Vasyl Stefanyk Precarpathian National University, 76018, Shevchenko street, 57 Ivano-Frankivsk, Ukraine

\section{Ostapiak Z.M.}

zinovii.ostapiak@pu.if.ua http://orsid.org/0000-0001-7687-161X

Vasyl Stefanyk Precarpathian National University, 76018, Shevchenko street, 57 Ivano-Frankivsk, Ukraine

\section{Mytskan T.S.}

tania_mytskan@ukr.net

http://orsid.org/0000-0002-4164-2961

Vasyl Stefanyk Precarpathian National University, 76018, Shevchenko street, 57 Ivano-Frankivsk, Ukraine

\section{Інформація про авторів}

\section{Мицкан Б.М.}

bogomdan_21@ukr.net http://orsid.org/0000-0002-5853-713X

Прикарпатський національний університет імені Василя Стефаника

вул. Шевченка, 57, 76018, м. Івано-Франківськ, Україна

\section{Остап'як 3.М.}

zinovii.ostapiak@pu.if.ua http://orsid.org/0000-0001-7687-161X

Прикарпатський національний університет імені Василя Стефаника

вул. Шевченка, 57, 76018, м. Івано-Франківськ, Україна

\section{Мицкан T.C.}

tania_mytskan@ukr.net http://orsid.org/0000-0002-4164-2961

Прикарпатський національний університет імені Василя Стефаника

вул. Шевченка, 57, 76018, м. Івано-Франківськ, Україна 